\title{
Teratosphaeria pseudoeucalypti on eucalyptus in Brazil
}

\author{
Tonimara de Souza Cândido ${ }^{1}$, André Costa da Silva ${ }^{1}$, Lúcio Mauro da Silva Guimarães ${ }^{1}$, Hélvio Gledson \\ Maciel Ferraz ${ }^{1}$, Norton Borges Júnior ${ }^{2} \&$ Acelino Couto Alfenas ${ }^{1}$
}

${ }^{1}$ Departamento de Fitopatologia, Universidade Federal de Viçosa, 36570-900, Viçosa, MG, Brazil; ${ }^{2} \mathrm{CMPC}$ Celulose Riograndense, Rua São Geraldo 1680, 92500-000, Guaíba, RS, Brazil

Author for correspondence: Acelino C. Alfenas, e-mail: aalfenas@ufv.br

\begin{abstract}
A new foliar disease caused by Teratosphaeria pseudoeucalypti on eucalyptus (E. globulus, E. urophylla x E. globulus and E. nitens $\mathrm{x}$ E. globulus) in Brazil is described. The disease is characterized by leaf spots of variable sizes and shapes, resulting in leaf blight and premature defoliation. Based on the morphological characteristics and multilocus phylogenetic analysis of the EF-1 $\alpha, \beta-\mathrm{T}$ and ITS-2 gene regions of five isolates, the fungus was identified as T. pseudoeucalypti. This is the first report of this pathogen outside Australia and a method for sporulation in culture is described.
\end{abstract}

Key words: Eucalyptus spp., Forest Pathology, kirramyces leaf blight, phylogenetic analysis.

Global expansion of clonal plantations of Eucalyptus spp. has occurred in recent years to meet the growing demand for wood fiber. Concomitantly, several diseases caused mainly by fungi and bacteria have emerged in eucalypt plantations (Alfenas et al., 2009). Among the foliar diseases of eucalypts in Brazil, those caused by species of Teratosphaeria are of particular interest due to intense defoliation, potentially leading to a decrease in tree growth as a result of the reduced photosynthetic capacity of the diseased plants (Alfenas et al., 2009). These fungi cause a complex of diseases on Eucalyptus spp. known as Teratosphaeria Leaf Disease (TLD).

In Brazil, seven species have been reported associated with TLD: T. nubilosa, T. suberosa, T. suttonii, T. ohnowa, T. perpendicularis, T. pseudafricana and T. flexuosa (Alfenas et al., 2009; Crous et al., 2006; Pérez et al., 2009a; Teodoro et al., 2012). However, there may be other species causing TLD in eucalyptus in Brazil (Teodoro et al., 2012). In 2012, clonal trials of Eucalyptus spp. in southern Brazil showed severe defoliation caused by a Teratosphaeria sp. (Figure 1A). The aim of this study was to identify the species of Teratosphaeria as the causal agent of this disease.

Infected Eucalyptus leaves exhibiting TLD symptoms (Figure 1A-C) were collected in clonal trials of E. globulus, E. urophylla x E. globulus and E. nitens x $E$. globulus at the Horto Florestal Capão do Leão ( $31^{\circ}$ 6'43" S, 52 3'19" W), Cristal (RS), Brazil (Table 1). Leaf samples from 10-month-old plants were collected from clones that were severely affected by the fungus. The leaf samples were kept in a moist chamber for $24 \mathrm{~h}$ in the laboratory at room temperature $\left(25^{\circ} \mathrm{C} \pm 3^{\circ} \mathrm{C}\right)$. After incubation, the conidial mass from a single pycnidium was transferred aseptically to $2 \%$ malt extract agar (MEA). The isolates were grown at $20^{\circ} \mathrm{C}$ under $12 \mathrm{~h}$ photoperiod and $40 \mu \mathrm{mol} \mathrm{s}^{-1} \mathrm{~m}^{-2}$ light intensity for 30 days. Representative specimens of the fungus were deposited in the local herbarium (Herbarium VIC) and pure cultures corresponding to each herbarium specimen were obtained and used in the work (but lost during storage at a later stage). The herbarium accession numbers and temporary culture codes (LPF - for Laboratório de Patologia Florestal, Departamento de Fitopatologia, UFV) were as follows: VIC 42699/LPF 521, VIC 42700/LPF 522, VIC 42701/LPF 523, VIC 42702/LPF 524, VIC 42703/DPF 606. Information for each specimen is presented in Table 1.

To induce in vitro sporulation, inoculum plugs of four isolates of the fungus grown on MEA (Figure 1F) were each added to a $125 \mathrm{~mL}$ Erlenmeyer flask containing tomato juice + calcium carbonate liquid medium ( $10 \%$ tomato juice and $2 \% \mathrm{CaCO}_{3}$ ) and incubated under agitation at $130 \mathrm{rpm}$ (Shaker, Thermo scientific, MaxQ 4000) at $20 \pm 1^{\circ} \mathrm{C}$ for 10 days in the dark and 5 days in the light. After incubation, the fungal structures were mounted in lacto-glycerol (1:1:1 lactic acid:glycerol:water) and observed under a light microscope (Olympus BX53), and the images were captured with a camera (Olympus Q-Color 5TM America INC). Each isolate was assessed for conidial sizes (length and width), shape, pigmentation and septa number of 50 randomly chosen conidia. Conidia were measured using the image analysis system Image Pro Plus (Version 7.0).

Genomic DNA of the five isolates was extracted from mycelia grown on MEA for 30 days (Wizard Genomic DNA Purification Kit, Promega). The DNA was quantified with a Nanodrop 2000c (Thermo Scientific) and adjusted to $10 \mathrm{ng} \mu \mathrm{L}^{-1}$. Target regions of the internal transcribed spacer regions 1 and 2, including the 5.8S rRNA gene (ITS), $\beta$-tubulin $(\beta-\mathrm{T})$ and translation elongation factor $1-\alpha(E F 1-\alpha)$ were amplified using the primers ITS-3 and 

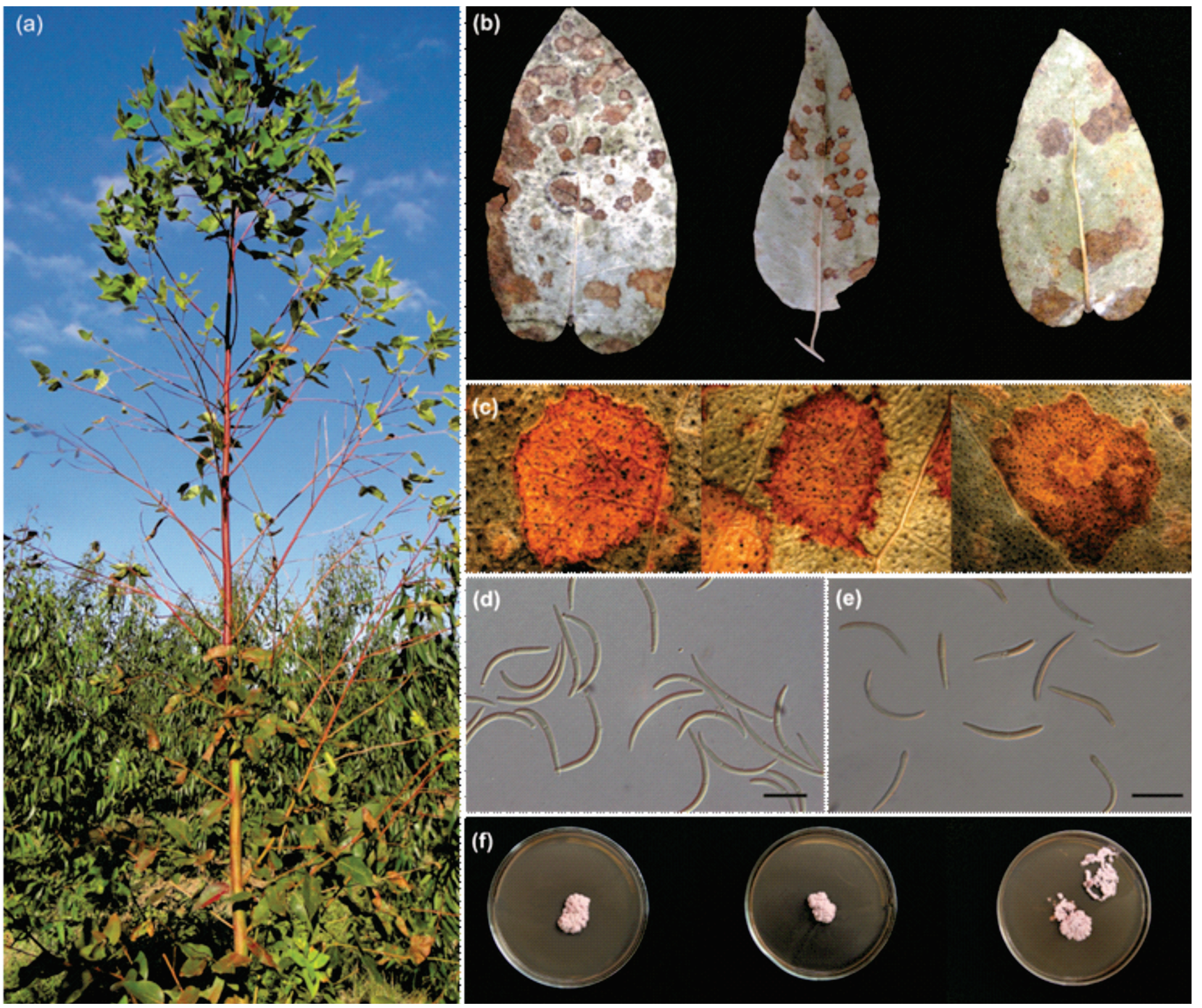

FIGURE 1 - Symptoms and signs of Teratosphaeria pseudoeucalypti on eucalyptus in southern Brazil: (a) Premature defoliation; (b) Leaf lesions; (c) Black conidiomata pycnidia formed on the lesions; (d) Conidia obtained directly from leaf lesions; (e) Conidia produced on liquid culture medium ( $10 \%$ tomato juice and $\left.2 \% \mathrm{CaCO}_{3}\right)$; (f) Colonies in malt-extract-agar. Scale bar $=20 \mu \mathrm{m}(\mathrm{d})$ and $25 \mu \mathrm{m}(\mathrm{e})$.

ITS-4 (Gardes \& Bruns, 1993), Bt2a and Bt2b (Glass \& Donaldson, 1995) and EF1-728F and EF1-986R (Carbone \& Kohn, 1999), respectively. Polymerase chain reactions (PCR) were performed using the following ingredients for each $25 \mu \mathrm{L}$ reaction: $12.5 \mu \mathrm{L}$ of Dream Taq ${ }^{\mathrm{TM}} \mathrm{PCR}$ Master Mix 2X (MBI Fermentas), $1.5 \mu \mathrm{L}$ of $10 \mu \mathrm{M}$ of each forward and reverse primer, $2 \mu \mathrm{L}$ of genomic DNA, and nuclease-free water to complete the total volume. The PCR conditions were performed as described previously by Andjic et al. (2010a) and performed using a Veriti 96 (Life Technologies) thermocycler. The PCR products were purified using GFX ${ }^{\mathrm{TM}}$ DNA and a Gel Band Purification Kit (GE) following the manufacturer's instructions. Sequencing was performed by Macrogen Inc. (www.macrogen.com). The same primers that were used for PCR were used for DNA sequencing. The sequences were then downloaded in FASTA format and aligned using the multiple sequence alignment program ClustalW (Thompson et al., 1997) built in MEGA v. 5 software (Tamura et al., 2011). Alignments were checked, and manual adjustments were made when necessary. Gaps (insertions/deletions) were treated as missing data. The Bayesian Inference (BI) method was used to construct phylogenetic trees using MrBayes v. 3.1.2 (Ronquist \& Huelsenbeck, 2003). The substitution model was chosen based on the Akaike information criterion (AIC) using MrModelTest v. 3.2 software (Nylander, 2004). The probability of a posterior tree distribution was calculated using an MCMC algorithm (Metropoliscoupled Markov Chain Monte Carlo) of two chains from a random tree with 10 million generations, and $25 \%$ of the first trees were discarded. The MCMC convergence and effective sample size were checked using the Tracer v. 1.4 


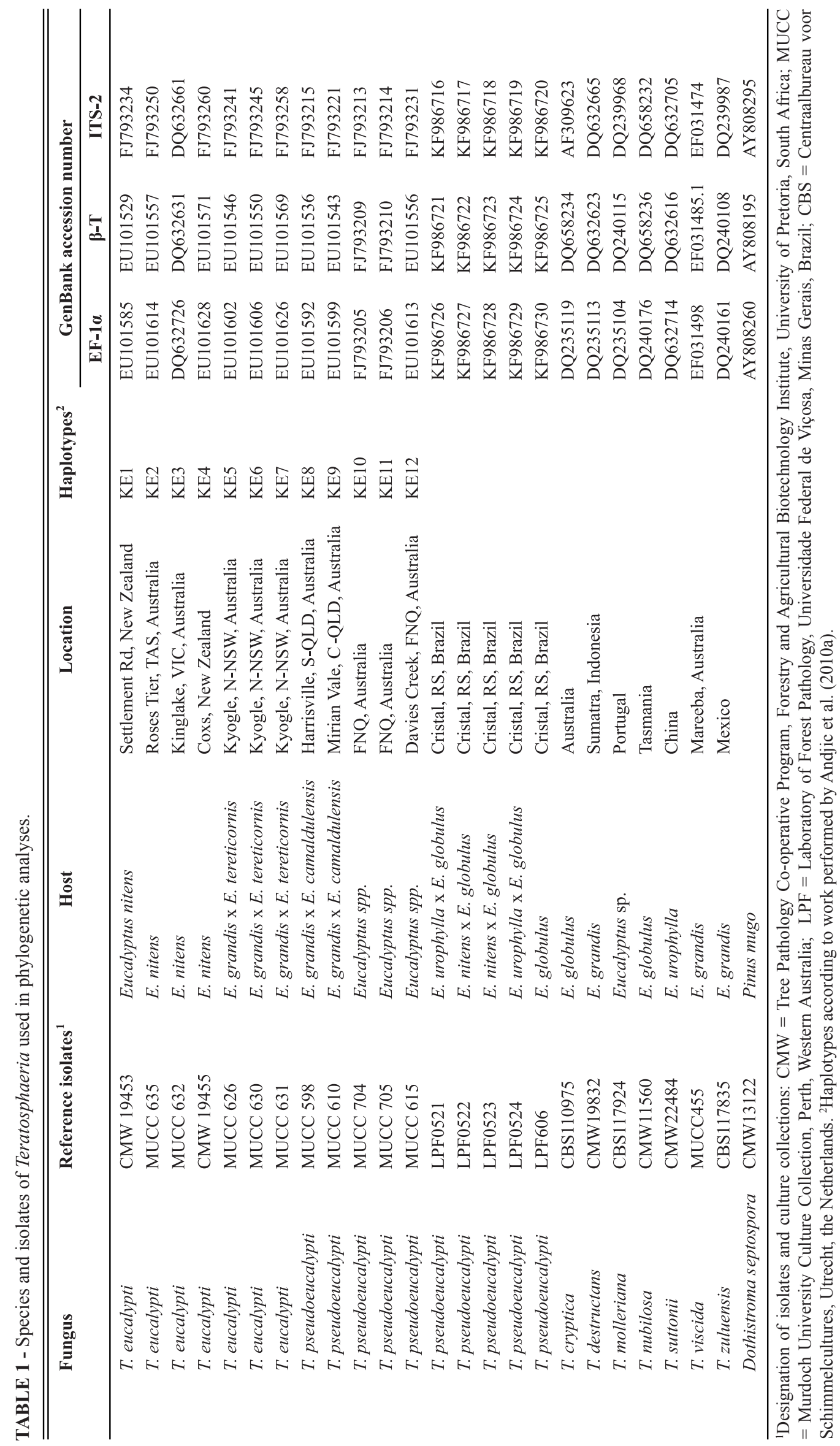


(Rambaut \& Drummond, 2007). Phylogenetic trees were viewed and edited in the FigTree v. 1.3.1. (http://tree.bio. ac.uk/software). The sequences obtained in this study were deposited in GenBank (www.ncbi.nlm.nih.gov/genbank), from which sequences of seven isolates of $T$. eucalypti, five isolates of $T$. pseudoeucalypti and a representative of each of the species T. cryptica, T. suttonii, T. zuluensis, $T$. molleriana, T. nubilosa, T. destructans and T. viscila were retrieved for comparison (Table 1). The isolates of T. eucalypti and T. pseudoeucalypti used in phylogenetic analysis were considered distinct haplotypes as described elsewhere (Andijc et al., 2010a). The sequences of Dothistroma septospora were used as an outgroup (Table 1).

The conidia of the studied isolates showed morphological characteristics similar to those of $T$. pseudoeucalypti Andjic, T.I. Burgess previously described and found in Australia (Andjic et al., 2010a). The fungus sporulated profusely in culture. The conidia produced in vitro were hyaline to light brown and straight to variously curved with narrowing ends and 0-3 septa (three septa were rare), while conidia obtained directly from the leaves were larger and more curved (Figure 1D-E). In addition, conidia examined directly from the leaves were longer (37 to $66 \mu \mathrm{m}$ - average $53.3 \mu \mathrm{m}$ ) and wider ( 3 to $5 \mu \mathrm{m}$ - average $3.7 \mu \mathrm{m}$ ) in relation to those produced in vitro, 18.5 to $59 \mu \mathrm{m}$ (average 37.4 $\mu \mathrm{m}$ ) and 2.5 to $5 \mu \mathrm{m}$ (average $3.5 \mu \mathrm{m}$ ), respectively.

Identification of $T$. pseudoeucalypti is difficult and inconclusive based solely on morphology, as many Teratosphaeria species are morphologically indistinguishable (Andjic et al., 2010b). Examples include T. eucalypti and T. pseudoeucalypti, which are considered morphologically similar (Andjic et al., 2010a), making it difficult to identify these species based on this trait. Currently, the distinction between species is primarily based on DNA sequence comparisons (Crous, 2009). Considering the three gene regions ( $\beta$-T, EF$1 \alpha$ and ITS-2), there were no differences among the Brazilian isolates. Bayesian inference of concatenated genes grouped the isolates from Brazil with isolates of T. psendoeucalypti (Figure 2),

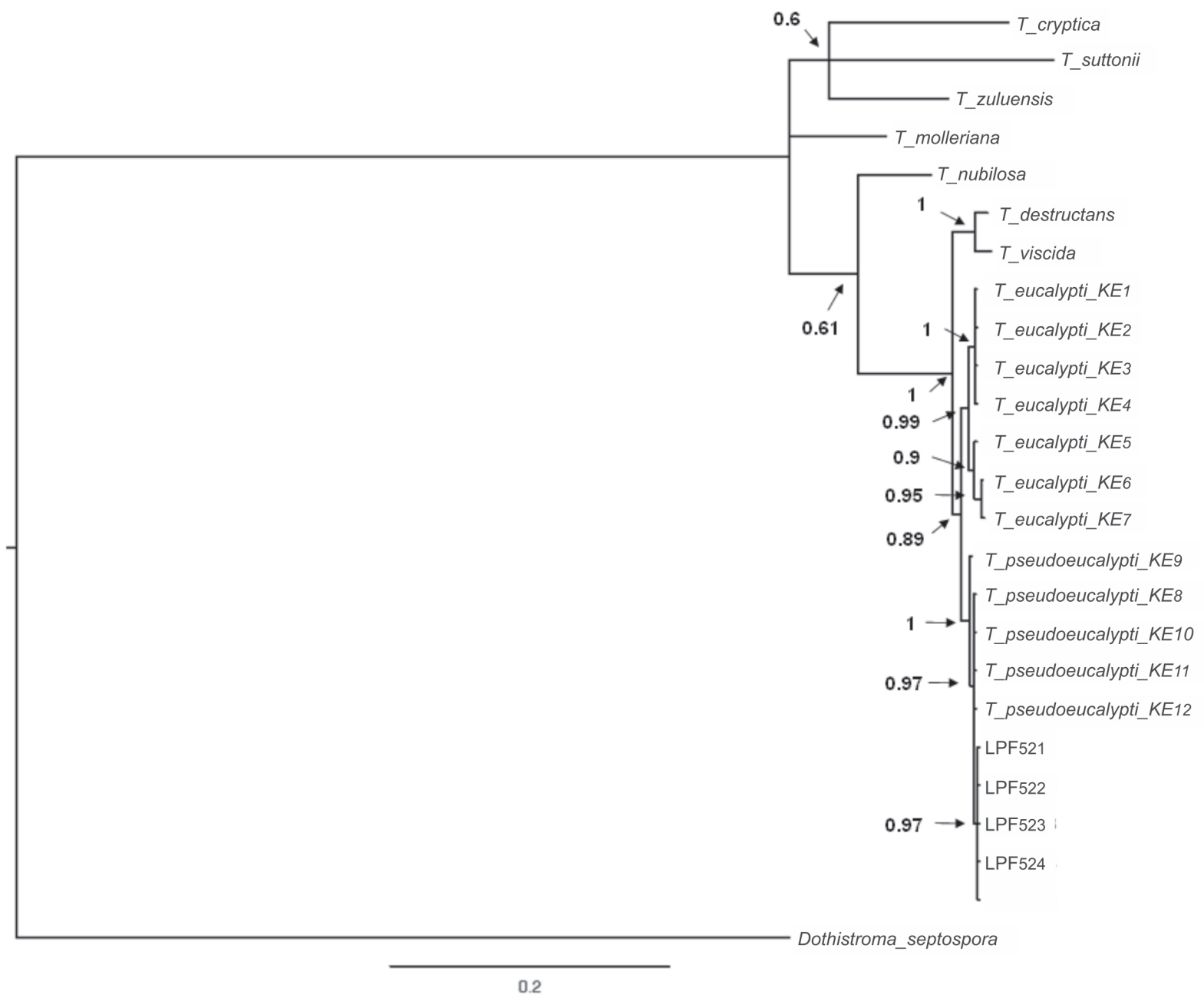

FIGURE 2 - Multilocus phylogenetic tree for partial sequences of the EF- $1 \alpha, \beta$-tubulin and ITS-2 genes by Bayesian analysis for isolates obtained in this study (LPF). Probability values are indicated on the branches. Dothistroma septospora was used as an outgroup. The identification of isolated Teratosphaeria eucalypti and T. pseudoeucalypti are according to the identification of a haplotype (KE) by Andjic et al. (2010a) as indicated in the Table 1. The scale bar indicates the fraction of substitution per site. 
though the sequences of the Brazilian isolates differed slightly from those previously described in Australia by Andjic et al. (2010a).

This is the first report of $T$. pseudoeucalypti outside Australia. The fungus was found in four clones (E. globulus, E. urophylla $\mathrm{x}$ E. globulus and E. nitens x E. globulus) severely affected by the disease. In each case, one of the parents was E. globulus, considered one of the most susceptible species to Teratosphaeria spp. (Passador et al., 2012). According to Hunter et al. (2011), T. destructans, $T$. pseudoeucalypti and T. viscidus are most destructive on $E$. grandis and its hybrids in tropical and subtropical regions. In our study, the clones were highly susceptible to $T$. pseudoeucalypti with diseased leaves covered by pycnidia and cirri of conidia, which may constitute an important source of inoculum.

Teratosphaeria spp. were first reported on eucalyptus in Australia and likely dispersed from Australia to other countries, including South Africa and Spain (Crous et al., 2004), Brazil (Pérez et al., 2009a), Portugal (Hunter et al., 2008), Chile (Crous et al., 2009), and Uruguay (Pérez et al., 2009b). Recently, plantings of hybrid E. grandis x $E$. camaldulensis in Queensland, Australia suffered severe outbreaks and damage by T. pseudoeucalyti. The impact of this disease in Australia has increased annually (Andjic et al., 2010a). The leaf symptoms caused by T. pseudoencalypti are variable and similar to those caused by $T$. eucalypti and $T$. destructans, depending on the host and number of mature leaves at the time of infection. In Queensland, $T$. pseudoeucalypti is considered the most aggressive species of Teratosphaeria established in the region and has been identified in nurseries and in the field (Andjic et al., 2010a).

The identification of T. pseudoeucalypti and the consequent damage to the eucalyptus plants in Brazil has led to substantial concern regarding the dissemination of this pathogen into other countries in South America where E. globulus is planted extensively, such as Uruguay, Chile, Colombia, Ecuador and Peru (Potts et al., 2004). Another problem is that eucalyptus plantations in South America, and especially in Brazil, have large planting areas of the same genetic material; thus, potential losses caused by the disease can increase considerably.

Currently, Teratosphaeria nubilosa is the most important Teratosphaeria species causing TLD in eucalyptus in Brazil (Teodoro et al., 2012). With the identification of T. pseudoeucalypti in south Brazil and the damage in plantations in Australia, this species of Teratosphaeria could become one of the most aggressive species to eucalyptus in Brazil. The most appropriate strategy for the control of TLD would be the development of resistant or tolerant clones; however, further research is needed to select clones that are resistant to this new species of Teratosphaeria sp. In addition, knowledge of the life cycle of the pathogen is essential for setting strategies for disease control and reducing economic losses.

\section{ACKNOWLEDGEMENTS}

The authors are thankful to the Fundação de Amparo a Pesquisa do Estado de Minas Gerais - FAPEMIG, the Conselho Nacional de Desenvolvimento Científico e Tecnológico - CNPq and CMPC Celulose Riograndense for financial support. The authors also thank Danielle A. A. Arriel for his collaboration in this research.

\section{REFERENCES}

Alfenas AC, Zauza EAV, Mafia RG, Assis TF (2009) Clonagem e doenças do eucalipto. 2nd Ed. Viçosa, Brazil. Editora UFV.

Andjic V, Pegg GS, Carnegie AJ, Callister A, Hardy GEStJ, Burgess TI (2010a) Teratosphaeria pseudoeucalypti, new cryptic species responsible for leaf blight of Eucalyptus in subtropical and tropical Australia. Plant Pathology 59:900-912.

Andjic V, Whyte G, Hardy G, Burgess T (2010b) New Teratosphaeria species occurring on eucalypts in Australia. Fungal Diversity 43:27-38.

Carbone I, Kohn LM (1999) A method for designing primer sets for speciation studies in filamentous ascomycetes. Mycologia 91:553-556.

Crous PW (2009) Taxonomy and phylogeny of the genus Mycosphaerella and its anamorphs. Fungal Diversity 38: 1-24.

Crous PW, Groenewald JZ, Mansilla JP, Hunter GC, Wingfield MJ (2004) Phylogenetic reassessment of Mycosphaerella spp. and their anamorphs occurring on Eucalyptus. Studies in Mycology 50:195-214

Crous PW, Summerell BA, Carnegie AJ, Wingfield MJ, Groenewald JZ (2009) Novel species of Mycosphaerellaceae and Teratosphaeriaceae. Persoonia 23:119-146.

Crous PW, Wingfield MJ, Mansilla JP, Alfenas AC, Groenewald JZ (2006) Phylogenetic reassessment of Mycosphaerella spp. and their anamorphs occurring on Eucalyptus II. Studies in Mycology 55:99-131.

Gardes M, Bruns T (1993) ITS primers with enhanced specificity for basidiomycetes - application to the identification of mycorrhizae and rusts. Molecular Ecology 2:113-118.

Glass NL, Donaldson GC (1995) Development of primer sets designated for use with the PCR to amplify conserved regions from filamentous Ascomycetes. Applied and Environmental Microbiology 61:1323-1330.

Hunter GC, Crous PW, Carnegie AJ, Burgess TI, Wingfield MJ (2011) Mycosphaerella and Teratosphaeria diseases of Eucalyptus; easily confused and with serious consequences. Fungal Diversity 50:145-166.

Hunter GC, Van der Merwe NA, Burgess TI, Carnegie AJ, Wingfield BD, Crous PW, Wingfield MJ (2008) Global movement and population biology of Mycosphaerella nubilosa infecting leaves of cold-tolerant Eucalyptus globulus and E. nitens. Plant Pathology 57:235-242.

Nylander JAA (2004) MrModeltest Version 2. Program distributed by the author. Evolutionary Biology Centre, Uppsala University.

Passador MM, Lima PRL, De Pieri C, Harakava R, Finkenauer E, Furtado EL (2012) Teratosphaeria nubilosa em plantações comerciais de Eucalyptus globulus nas regiões Sul e Sudeste do 
T.S. Cândido et al.

Brasil. Summa Phytopathologica 38:11-16.

Pérez G, Slippers B, Wingfield BD, Finkenauer E, Wingfield MJ (2009a) Mycosphaerella leaf disease (MLD) outbreak on Eucalyptus globulus in Brazil caused by Teratosphaeria (Mycosphaerella) nubilosa. Phytopathologia Mediterranea 48:302-306.

Pérez CA, Wingfield MJ, Altier NA, Blanchette RA (2009b) Mycosphaerellaceae and Teratosphaeriaceae associated with Eucalyptus leaf diseases and stem cankers in Uruguay. Forest Pathology 39:349-360.

Potts BM, Vaillancourt RE, Jordan GJ, Dutkowski GW, Costa e Silva J, McKinnon GE, Steane DA, Volker P, Lopez G, Apiolaza LA, Li Y, Marques C, Borralho N (2004) Exploration of the Eucalyptus globulus gene pool, Eucalyptus in a Changing World. In: International IUFRO Conference 2004, Aveiro, Portugal, p. 46-61.

Rambaut A, Drummond AJ (2007) Tracer v1.4. Available at: http:// beast.bio.ed.ac.uk/ Tracer. Accessed on February 17, 2014.
Ronquist F, Huelsenbeck JP (2003) MrBayes Version 3.1.2: Bayesian phylogenetic inference under mixed models. Bioinformatics 19:1572-1574.

Tamura K, Peterson D, Peterson N, Stecher G, Nei M, Kumar S (2011) MEGA5: Molecular evolutionary genetics analysis using maximum likelihood, evolutionary distance, and maximum parsimony methods. Molecular Biology and Evolution 28:27312739.

Teodoro MG, Ferreira MA, Guimarães LMS, Mafia RG, Groenewald JZ, Crous PW, Alfenas AC (2012) Mycosphaerella and Teratosphaeria species associated with leaf diseases on Eucalyptus globulus in southern Brazil. Phytopathologia Mediterranea 51:355-364.

Thompson JD, Gibson TJ, Plewniak F, Jeanmougin FE, Higgins DG (1997) The Clustal X windows interface: flexible strategies for multiple sequence alignment aided by quality analysis tools. Nucleic Acids Research 24:4876-4882.

TPP-2014-0053

Submitted: 14 April 2014

Revisions requested: 28 April 2014

Accepted: 12 June 2014

Section Editor: Thomas Harrington 